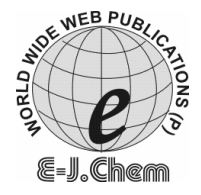

http://www.e-journals.net
ISSN: 0973-4945; CODEN ECJHAO

E-Journal of Chemistry

2009, 6(2), 523-530

\title{
Assessment of Water Quality Index for the Groundwater in Tumkur Taluk, Karnataka State, India
}

\author{
C. R. RAMAKRISHNAIAH* ${ }^{*}$, C. SADASHIVAIAH ${ }^{\#}$ and G. RANGANNA ${ }^{\S}$ \\ *Research Scholar, Department of Civil Engineering, S.I.T, Tumkur-572103. \\ \#Karavali Institute of Technology, Neerumarga, Mangalore-575023, India. \\ ${ }^{\S}$ Department of Mathematics, UGC-CSA, \\ Central College Campus, Bangalore University, Bangalore-560 001, India.
}

rama_bmsce@yahoo.com

Received 18 August 2008; Revised 29 November 2008; Accepted 11 December 2008

\begin{abstract}
The present work is aimed at assessing the water quality index (WQI) for the groundwater of Tumkur taluk. This has been determined by collecting groundwater samples and subjecting the samples to a comprehensive physicochemical analysis. For calculating the WQI, the following 12 parameters have been considered: $\mathrm{pH}$, total hardness, calcium, magnesium, bicarbonate, chloride, nitrate, sulphate, total dissolved solids, iron, manganese and fluorides. The WQI for these samples ranges from 89.21 to 660.56. The high value of WQI has been found to be mainly from the higher values of iron, nitrate, total dissolved solids, hardness, fluorides, bicarbonate and manganese in the groundwater. The results of analyses have been used to suggest models for predicting water quality. The analysis reveals that the groundwater of the area needs some degree of treatment before consumption, and it also needs to be protected from the perils of contamination
\end{abstract}

Keywords: Groundwater, Water quality standards, Water quality index, India

\section{Introduction}

Groundwater is used for domestic and industrial water supply and irrigation all over the world. In the last few decades, there has been a tremendous increase in the demand for fresh water due to rapid growth of population and the accelerated pace of industrialization. Human health is threatened by most of the agricultural development activities particularly in relation to excessive application of fertilizers and unsanitary conditions. Rapid urbanization, especially in developing countries like India, has affected the availability and quality of 
groundwater due to its overexploitation and improper waste disposal, especially in urban areas. According to $\mathrm{WHO}$ organization, about $80 \%$ of all the diseases in human beings are caused by water. Once the groundwater is contaminated, its quality cannot be restored by stopping the pollutants from the source. It therefore becomes imperative to regularly monitor the quality of groundwater and to device ways and means to protect it. Water quality index is one of the most effective tools ${ }^{1-4}$ to communicate information on the quality of water to the concerned citizens and policy makers. It, thus, becomes an important parameter for the assessment and management of groundwater. WQI is defined as a rating reflecting the composite influence of different water quality parameters. WQI is calculated from the point of view of the suitability of groundwater for human consumption.

The objective of the present work is to discuss the suitability of groundwater for human consumption based on computed water quality index values.

\section{Study area}

Tumkur taluk is located in the southeastern corner of Karnataka state between $13^{\circ} 06^{\prime} 30^{\prime \prime}$ to $13^{\circ} 31^{\prime}$ North latitude and $76^{\circ} 59^{\prime}$ to $77^{\circ} 19^{\prime}$ East longitude and (Figure 1) covers an area of 1043 sq.km with a population ${ }^{5}$ of $5,16,661$. The major sources of employment are agriculture, horticulture and animal husbandry, which engage almost $80 \%$ of the workforce. The major industries are that of chemicals, oil, cotton, soap, tools, food processing, rice mills, stone crushing and mining. Occurrence, movement and storage of groundwater are influenced by lithology, thickness and structure of rock formations. Weathered and fractured granites, granitic gneiss and shale form the main aquifer of Tumkur taluk (Figure 2).

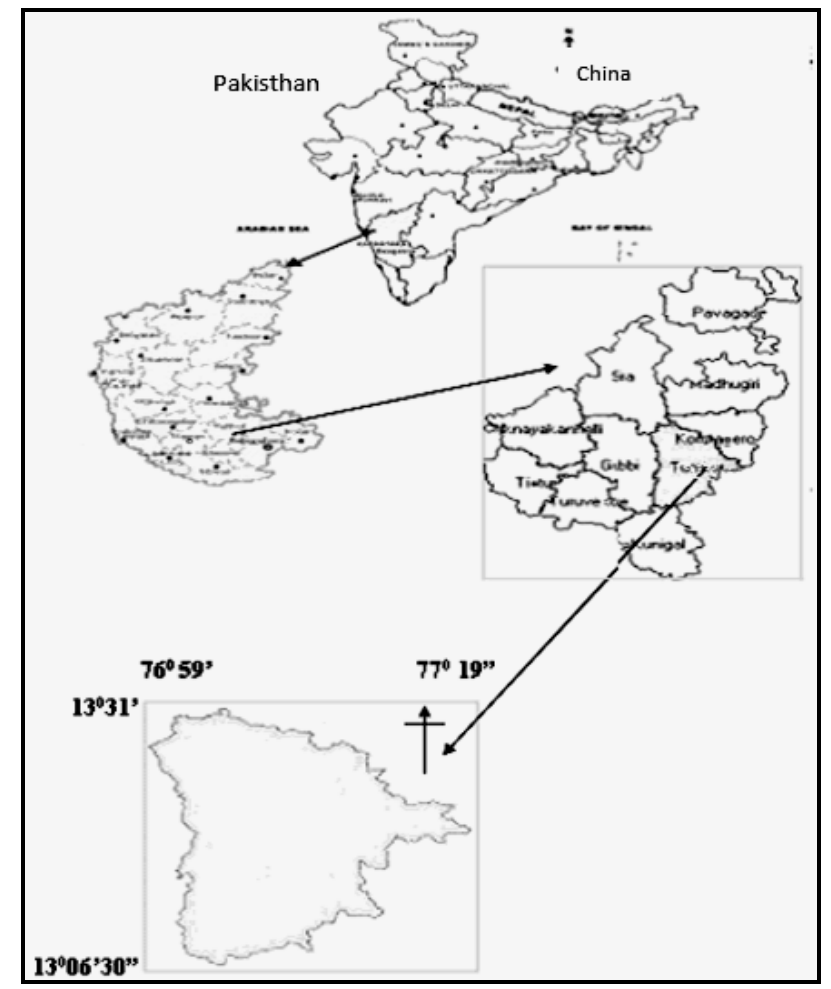

Figure 1. Location map of the study area. 
Groundwater in the study area occurs under water table conditions in the weathered and fractured granite, Gneisses. There is no perennial river in the study area. The major ion chemistry of groundwater of Tumkur taluk has not been studied earlier.

\section{Methodology}

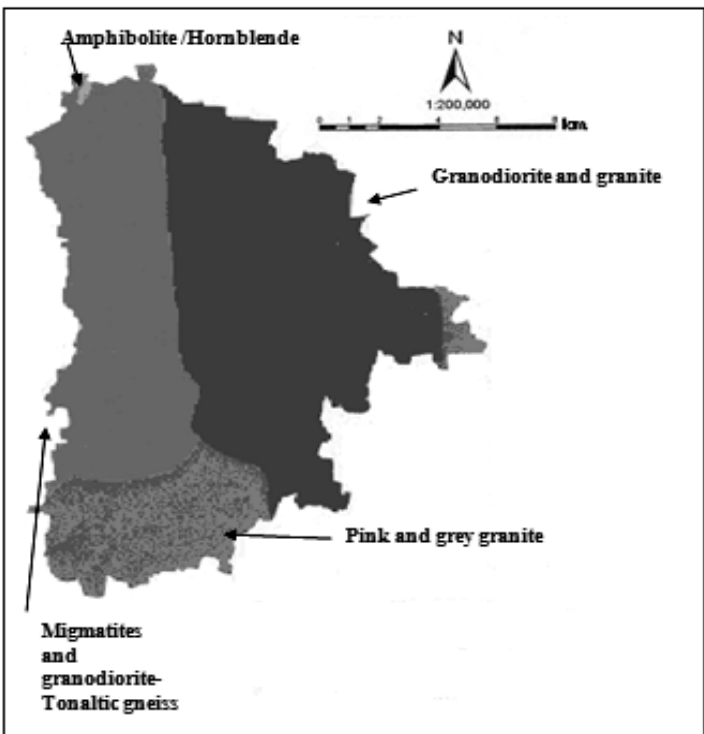

Figure 2. Geological map of study area.

Groundwater samples were collected from 269 locations during pre-monsoon period (February 2006) (Figure 3). Each of the groundwater samples was analyzed for 17 parameters such as $\mathrm{pH}$, electrical conductivity, TDS, total hardness, bicarbonate, carbonate, chloride, sulphate, phosphate, nitrate, fluoride, calcium, magnesium, sodium, potassium, iron and manganese using standard procedures recommended by APHA ${ }^{6}$.

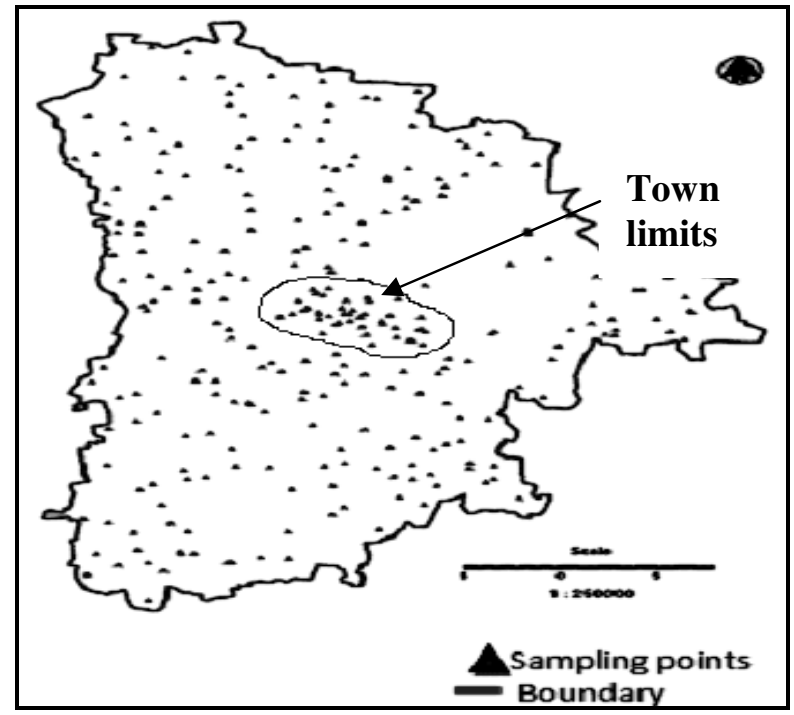

Figure 3. Groundwater sampling locations. 
The chemical parameters obtained were used for regression analysis. The regression analysis is carried out by taking TDS as dependent variable and $\mathrm{Ca}, \mathrm{Mg}, \mathrm{Cl}, \mathrm{SO}_{4}, \mathrm{NO}_{3}, \mathrm{Na}$ and $\left(\mathrm{HCO}_{3}+\mathrm{CO}_{3}\right)$ as independent variables. Trend analysis represents the process of using the analysed data for predictions. This may be used to predict or forecast values of the dependent variable. The regression models can be used to find out the ionic concentration of the groundwater samples, if the dependent variable TDS is measured for different locations, by inverse calculations. Water quality index is calculated from the point of view of suitability of groundwater for human consumption.

\section{Results and Discussion}

The chemical analyses of the groundwater and the percent compliance with the Indian Standards ${ }^{7}$ and $\mathrm{WHO}^{8}$ are summarized in Table 1 . Normal statistics of water quality parameters of 269 groundwater samples are presented in Table 2.

Table 1. Comparison of groundwater quality with drinking water standards, Indian and WHO.

\begin{tabular}{lcccc}
\hline \multicolumn{1}{c}{ Parameters } & $\begin{array}{c}\text { Indian } \\
\text { Standard }\end{array}$ & $\begin{array}{c}\text { Percent } \\
\text { compliance }\end{array}$ & $\begin{array}{c}\text { WHO } \\
\text { Standard }\end{array}$ & $\begin{array}{c}\text { Percent } \\
\text { compliance }\end{array}$ \\
\hline $\mathrm{pH}$ & $6.5-8.5$ & 98.5 & $7.0-8.0$ & 91 \\
Electrical & & - & - & - \\
conductivity & - & & & \\
Total dissolved & 500 & 70 & 1,000 & 96.5 \\
solids & & & & \\
Total hardness as & 300 & 70 & 100 & 0.5 \\
CaCO, mg/L & & - & - & - \\
Carbonate, mg/L & - & - & - & - \\
Bicarbonate, mg/L & - & 97 & 250 & 97 \\
Chloride, mg/L & 250 & 100 & 250 & 100 \\
Sulphate, mg/L & 200 & - & - & - \\
Phosphate, mg/L & - & 51.5 & 50 & 56.5 \\
Nitrate, mg/L & 45 & 30 & 1 & 30 \\
Fluoride, mg/L & 1 & 96 & 75 & 96 \\
Calcium, mg/L & 75 & 26 & 30 & 26 \\
Magnesium, mg/L & 30 & - & 200 & - \\
Sodium, mg/L & - & - & - & - \\
Potassium, mg/L & - & 0.5 & 0.1 & 0.5 \\
Iron, mg/L & 0.3 & 17 & 0.05 & 17 \\
Manganese, mg/L & 0.1 & &
\end{tabular}

The following regression models have been obtained from the results of analysis of water samples. Considering a known value of TDS, the percentage contribution of each ion can be obtained by substituting an average ionic value for the entire study area for premonsoon season.

$$
\begin{aligned}
& \mathrm{Ca}^{++}=0.0368 \mathrm{TDS}+15.435 \\
& \mathrm{Mg}^{++}=0.0594 \mathrm{TDS}+19.311 \\
& \mathrm{HCO}_{3}{ }^{-+} \mathrm{CO}_{3}^{--}=0.1063 \mathrm{TDS}+157.26 \\
& \mathrm{Cl}^{-}=0.1914 \mathrm{TDS}+8.6634 \\
& \mathrm{SO}_{4}{ }^{--}=0.0383 \mathrm{TDS}+12.902
\end{aligned}
$$




$$
\begin{aligned}
& \mathrm{NO}_{3}{ }^{-}=0.0528 \text { TDS }+32.852 \\
& \mathrm{Na}^{+}=0.0378 \text { TDS }+23.685 \\
& \text { Total hardness }=0.9937(\mathrm{Ca}+\mathrm{Mg}) \text { Hardness }+1.7501 \\
& \text { Conductivity, } \mu \text { mohs } / \mathrm{cm}=1.9151 \text { TDS }-2.6814
\end{aligned}
$$

Table 2. Normal statistics of water quality parameters of groundwater samples.

\begin{tabular}{lcccccccc}
\hline \multirow{2}{*}{\multicolumn{1}{c}{ Parameters }} & \multicolumn{7}{c}{ Pre-monsoon samples (2006) } \\
\cline { 2 - 9 } & Min & Max & AM & SD & CV & Q1 & Med & Q3 \\
\hline EH & 6.61 & 8.90 & 7.5 & 0.416 & 5.548 & 7.42 & 7.46 & 7.48 \\
Electrical conductivity & 130 & 3000 & 874.3 & 85.48 & 81.23 & 530 & 760 & 560 \\
$\mu$ mohs/cm & & & & & & & & \\
Total dissolved solids & 70 & 1500 & 453.3 & 479.5 & 54.84 & 280 & 400 & 560 \\
Total hardness as & 70 & 1060 & 271.4 & 129.1 & 47.55 & 224 & 248 & 272 \\
CaCO $_{3}$ & 45 & 550 & 199.4 & 47.86 & 27.77 & 155 & 196 & 226 \\
Bicarbonate & 4.9 & 662.3 & 105.2 & 12.68 & 55.96 & 49.98 & 79.98 & 141.5 \\
Chloride & 1.5 & 174 & 29.93 & 29.65 & 32.92 & 12 & 22.5 & 35 \\
Sulphate & 0.05 & 5.6 & 1.49 & 1.266 & 85.15 & 0.6 & 1.1 & 1.9 \\
Phosphate & 261 & 0.44 & 54.3 & 48.58 & 144.2 & 17.72 & 42.09 & 69.5 \\
Nitrate & 0.02 & 3.2 & 1.43 & 23.26 & 65.33 & 1.0 & 1.5 & 1.8 \\
Fluoride & 1.60 & 174.7 & 31.21 & 21.3 & 68.22 & 17.64 & 27.25 & 38.48 \\
Calcium & 0.24 & 229.4 & 47.06 & 29.2 & 62.06 & 29.4 & 41.8 & 57.83 \\
Magnesium & 4 & 140 & 29.65 & 19.95 & 99.05 & 27 & 35 & 48 \\
Sodium & 1 & 27 & 3.79 & 3.229 & 49.47 & 2 & 3 & 5 \\
Potassium & 0.1 & 4.72 & 1.95 & 48.58 & 89.46 & 1.56 & 1.9 & 2.2 \\
Iron & 0.05 & 5.5 & 0.76 & 0.624 & 43.55 & 0.2 & 0.3 & 0.85 \\
Manganese & & &
\end{tabular}

All units except $p H$ and Electrical conductivity are in $m g / l$, Min-Minimum, Max-Maximum, AMArithmetic mean, SD-Standard deviation, CV-Coefficient variation, Q1-Median of the lower half, Q3Median of the upper half, Med-Median

For computing WQI three steps are followed. In the first step, each of the 19 parameters has been assigned a weight (wi) according to its relative importance in the overall quality of water for drinking purposes (Table 3). The maximum weight of 5 has been assigned to the parameter nitrate due to its major importance in water quality assessment. Magnesium which is given the minimum weight of 1 as magnesium by itself may not be harmful. Other In the second step, the relative weight $\left(\mathrm{W}_{\mathrm{i}}\right)$ is computed from $\mathrm{t}$ he following equation:

$$
\mathrm{W}_{\mathrm{i}}=\frac{\mathrm{w}_{\mathrm{i}}}{\sum_{\mathrm{i}=1}^{\mathrm{n}} \mathrm{w}_{\mathrm{i}}}
$$

Where, $\mathrm{W}_{\mathrm{i}}$ is the relative weight, $\mathrm{w}_{\mathrm{i}}$ is the weight of each parameter and $\mathrm{n}$ is the number of parameters. Calculated relative weight $\left(\mathrm{W}_{\mathrm{i}}\right)$ values of each parameter are also given in Table 3 .

In the third step, a quality rating scale $\left(\mathrm{q}_{\mathrm{i}}\right)$ for each parameter is assigned by dividing its concentration in each water sample by its respective standard according to the guidelines laid down in the BIS and the result multiplied by 100 :

$$
\mathrm{q}_{\mathrm{i}}=\left(\mathrm{C}_{\mathrm{i}} / \mathrm{S}_{\mathrm{i}}\right) \times 100
$$


Table 3. Relative weight of chemical parameters.

\begin{tabular}{lccc}
\hline Chemical parameters & Indian Standards & Weight $\left(\mathrm{w}_{\mathrm{i}}\right)$ & Relative weight $\left(\mathrm{W}_{\mathrm{i}}\right)$ \\
\hline $\mathrm{pH}$ & $6.5-8.5$ & 4 & 0.09756 \\
Total hardness $(\mathrm{TH})$ & $300-600$ & 2 & 0.04878 \\
Calcium & $75-200$ & 2 & 0.04878 \\
Magnesium & $30-100$ & 2 & 0.02439 \\
Bicarbonate & $244-732$ & 3 & 0.07317 \\
Chloride & $250-1,000$ & 3 & 0.07317 \\
Total dissolved & $500-2,000$ & 4 & 0.09756 \\
solids (TDS) & $1-1.5$ & 4 & 0.09756 \\
Fluoride & $0.1-0.3$ & 4 & 0.09756 \\
Manganese & $45-100$ & 5 & 0.12195 \\
Nitrate & $0.3-1.0$ & 4 & 0.09756 \\
Iron & $200-400$ & 4 & 0.09756 \\
Sulphate & & $\sum \mathrm{w}_{\mathrm{i}}=41$ & $\sum \mathrm{W}_{\mathrm{i}}=1.000$ \\
& &
\end{tabular}

Groundwater Quality Variation

where $\mathrm{q}_{\mathrm{i}}$ is the quality rating, $\mathrm{C}_{\mathrm{i}}$ is the concentration of each chemical parameter in each water sample in $\mathrm{mg} / \mathrm{L}$, and $\mathrm{S}_{\mathrm{i}}$ is the Indian drinking water standard for each chemical parameter in $\mathrm{mg} / \mathrm{L}$ according to the guidelines of the $\mathrm{BIS}^{7} 10500,1991$.

For computing the WQI, the SI is first determined for each chemical parameter, which is then used to determine the WQI as per the following equation

$$
\begin{aligned}
& \mathrm{SI}_{\mathrm{i}}=\mathrm{W}_{\mathrm{i}} \cdot \mathrm{q}_{\mathrm{i}} \\
& \mathrm{WQI}=\sum \mathrm{SI}_{\mathrm{i}}
\end{aligned}
$$

$\mathrm{SI}_{\mathrm{i}}$ is the subindex of ith parameter; $\mathrm{q}_{\mathrm{i}}$ is the rating based on concentration of ith parameter and $\mathrm{n}$ is the number of parameters. The computed WQI values are classified into five types, "excellent water" to "water, unsuitable for drinking".

Electrical conductivity of water is a direct function of its total dissolved salts ${ }^{9}$. Hence it is an index to represent the total concentration of soluble salts in water ${ }^{10}$. In our study area, the electrical conductivity of the groundwater samples varied between $130-3000 \mu \mathrm{S} / \mathrm{cm}$ during pre-monsoon.

The permissible total dissolved salts for drinking water is $500 \mathrm{mg} / \mathrm{L}$. In the absence of potable water source the permissible limit is upto $2000 \mathrm{mg} / \mathrm{L}$. It is found from the analysis, all the well water samples TDS is within the maximum limit of $2000 \mathrm{mg} / \mathrm{L}$ in pre-monsoon period. The range of TDS levels in the study area is $70-1500 \mathrm{mg} / \mathrm{L}$. Total 84 samples in premonsoon period show TDS value beyond the desirable limit of $500 \mathrm{mg} / \mathrm{L}$. The highest concentration of total dissolved solids was found to be $1500 \mathrm{mg} / \mathrm{L}$ at Devalapura $\left(\mathrm{N} 13.4878^{\circ}\right.$ $\mathrm{E} 77.10525^{\circ}$ ) due to dense residential area and due to intensive irrigation in that area. High values of TDS in groundwater are generally not harmful to human beings but high concentration of these may affect persons, who are suffering from kidney and heart diseases $^{11}$. Water containing high solids may cause laxative or constipation effects ${ }^{12}$.

During pre-monsoon season of the year 2006, based on the comparisons of chemical constituents with WHO (1994) standards, it is found that, for 269 water samples, eleven samples have total hardness value above maximum permissible limit of $500 \mathrm{mg} / \mathrm{L}$. Total hardness varies from 70 to $1060 \mathrm{mg} / \mathrm{L}$. The hardness values for the study area are found to be high for almost all locations for pre-monsoon and determined to fall above the desirable limit of WHO specification. According to Sawyer and McCarty's classification ${ }^{13}$ for hardness, 26 samples fall under the 
moderately hard class and 242 samples fall under the hard class to very hard class for premonsoon water samples.

Chloride is a widely distributed element in all types of rocks in one or the other form. Its affinity towards sodium is high. Therefore, its concentration is high in ground waters, where the temperature is high and rainfall is less. Soil porosity and permeability also has a key role in building up the chlorides concentration ${ }^{14}$. The chloride content in rural part of Tumkur taluk was found to be well within the permissible levels. The chloride content ranges from 5 to $662 \mathrm{mg} / \mathrm{L}$.

In Tumkur taluk, the nitrate value varies from 0.4 to $261 \mathrm{ppm}$ for the pre-monsoon period. For the post-monsoon period, the value varies from 0.39 to $149 \mathrm{ppm}$. The nitrate value for the study area is found to be more than 45 ppm as per WHO (1994) in 131 locations. More nitrate value is found in the rural part of the study area due to over-application of fertilizer, improper manure management practices, and improper operation and maintenance of septic systems.

In this study, the computed WQI values ranges from 89.21 to 660.56 and therefore, can be categorized into five types "excellent water" to "water unsuitable for drinking". Table 4 shows the percentage of water samples that falls under different quality. The high value of WQI at these stations has been found to be mainly from the higher values of iron, nitrate, total dissolved solids, hardness, fluorides, bicarbonate and manganese in the groundwater.

Table 4. Water quality classification based on WQI value

\begin{tabular}{ccc}
\hline WQI value & Water quality & $\begin{array}{c}\text { Percentage of water samples } \\
\text { (Pre-monsoon) }\end{array}$ \\
\hline$<50$ & excellent & 00 \\
$50-100$ & good water & 1.5 \\
$100-200$ & poor water & 63.5 \\
$200-300$ & very poor water & 22 \\
$>300$ & Water unsuitable & 13.0 \\
& for drinking & \\
\hline
\end{tabular}

The degree of a linear association between any two of the water quality parameters, as measured by the simple correlation coefficient (r), is presented in Table 5. Magnesium and chloride are highly interrelated among themselves. This interrelationship indicates that the hardness of the water is permanent in nature.

Table 5. Correlation coefficient matrix of water quality parameters.

\begin{tabular}{ccccccccccccc}
\hline $\begin{array}{c}\text { Para- } \\
\text { meter }\end{array}$ & $\mathrm{pH}$ & $\mathrm{TH}$ & $\mathrm{Ca}$ & $\mathrm{Mg}$ & $\mathrm{HCO}_{3}$ & $\mathrm{Cl}$ & $\mathrm{TDS}$ & $\mathrm{FL}$ & $\mathrm{Mn}$ & $\mathrm{NO}_{3}$ & $\mathrm{Fe}$ & $\mathrm{SO}_{4}$ \\
\hline $\mathrm{pH}$ & 1 & & & & & & & & & & & \\
$\mathrm{TH}$ & -0.28 & 1 & & & & & & & & & & \\
$\mathrm{Ca}$ & -0.22 & 0.356 & 1 & & & & & & & & & \\
$\mathrm{Mg}$ & -0.21 & 0.912 & -0.06 & 1 & & & & & & & & \\
$\mathrm{HCO}_{3}$ & -0.14 & 0.479 & 0.104 & 0.469 & 1 & & & & & & & \\
$\mathrm{Cl}$ & -0.21 & 0.767 & 0.287 & 0.698 & 0.015 & 1 & & & & & & \\
$\mathrm{TDS}$ & -0.23 & 0.709 & 0.342 & 0.61 & 0.208 & 0.746 & 1 & & & & & \\
$\mathrm{FL}$ & 0.111 & -0.04 & -0.14 & 0.015 & 0.085 & -0.14 & -0.16 & 1 & & & & \\
$\mathrm{Mn}$ & -0.03 & -0.08 & -0.12 & -0.04 & 0.097 & -0.16 & -0.07 & 0.057 & 1 & & & \\
$\mathrm{NO}_{3}$ & -0.24 & 0.181 & 0.329 & 0.047 & 0.096 & -0.12 & 0.144 & 0.007 & 0.113 & 1 & & \\
$\mathrm{Fe}$ & -0 & 0.009 & -0 & 0.007 & 0.043 & 0.024 & -0.01 & 0.048 & 0.087 & -0.13 & 1 & \\
$\mathrm{SO}_{4}$ & -0.24 & 0.364 & 0.249 & 0.282 & 0.269 & 0.014 & 0.225 & 0.059 & 0.038 & 0.417 & -0.1 & 1 \\
\hline
\end{tabular}




\section{Conclusions}

The WQI for 269 samples ranges from 89.21 to 660.56. Almost ninety nine percent of the samples exceeded 100, the upper limit for drinking water. The high value of WQI at these stations has been found to be mainly from the higher values of iron, nitrate, total dissolved solids, hardness, fluorides, bicarbonate, chloride and manganese in the groundwater. About $63.5 \%$ of water samples are poor in quality. In this part, the groundwater quality may improve due to inflow of freshwater of good quality during rainy season. Magnesium and chloride are significantly interrelated and indicates that the hardness of the water is permanent in nature. The analysis reveals that the groundwater of the area needs some degree of treatment before consumption, and it also needs to be protected from the perils of contamination

\section{References}

1. $\quad$ Mishra P C and Patel R K, Indian J Environ Ecoplan., 2001, 5(2), 293-298.

2. $\quad$ Naik S and Purohit K M, Indian J Environ Ecoplan., 2001, 5(2) 397-402.

3. Singh D F, Proc Acad Environ Biol., 1992, 1(1), 61-66.

4. $\quad$ Tiwari T N and Mishra M A, Indian J Environ Proc., 1985, 5, 276-279.

5. Director of Census Operations. District Census Handling of Karnataka, Census of India, 2001.

6. APHA (American Public Health Association) Standard method for examination of water and wastewater, NW, DC 20036, 1994.

7. BIS (Bureau of Indian Standards) 10500, Indian standard drinking waterspecification, First revision, 1991, pp 1-8.

8. WHO (World Health Organization) Guidelines for drinking water quality, $2^{\text {nd }}$ Ed., 1993, Vol 1, p 188.

9. Harilal C C, Hashim A, Arun P R and Baji S, J Ecology, Environment and Conservation, 2004, 10(2), 187-192.

10. Purandara B K, Varadarajan N and Jayashree K, Poll Res., 2003, 22(2), 189.

11. Gupta S, Kumar A, Ojha C K and Singh G, J Environmental Science and Engineering., 2004, 46(1), 74-78.

12. Kumaraswamy N, J Pollut Res., 1999, 10(1), 13-20.

13. Sawyer G N, Carthy Mc D L, Chemistry of sanitary Engineers, $2^{\text {nd }}$ Ed., McGraw Hill, New York, 1967, p 518.

14. Chanda D K, Hydrology J, 1999, 7(5), 431-439. 


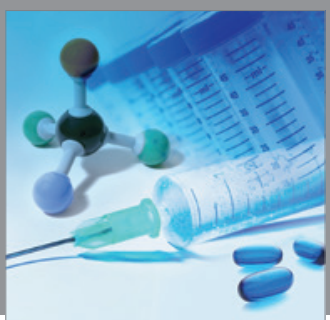

International Journal of

Medicinal Chemistry

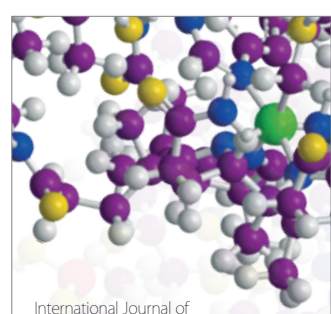

Carbohydrate Chemistry

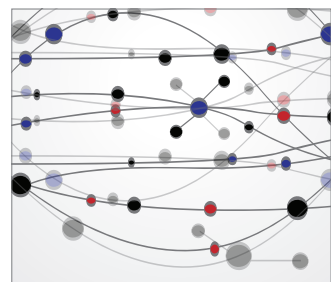

The Scientific World Journal
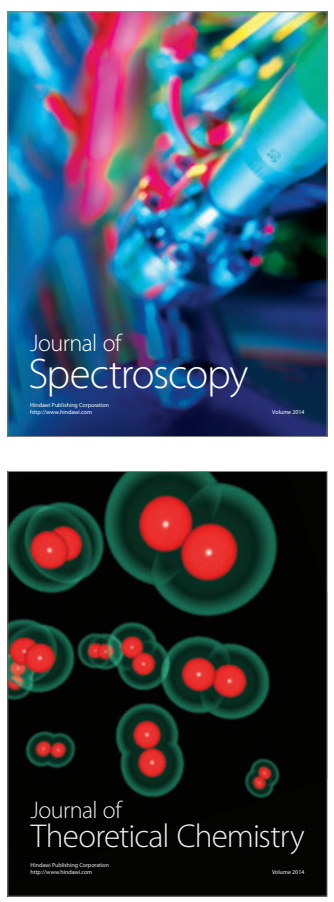
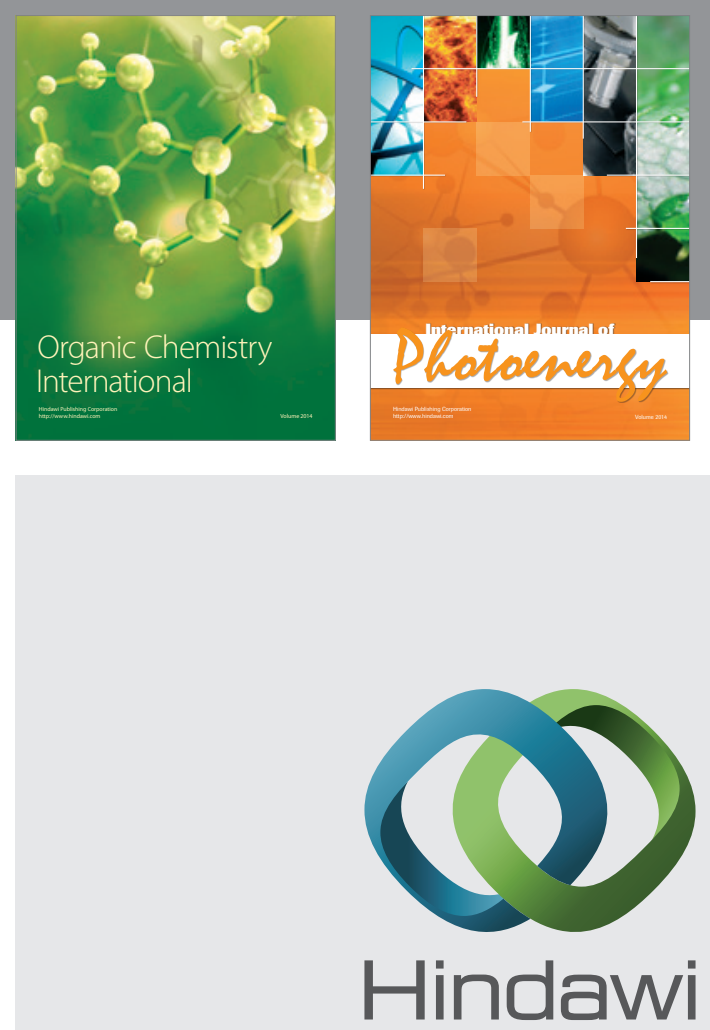

Submit your manuscripts at

http://www.hindawi.com
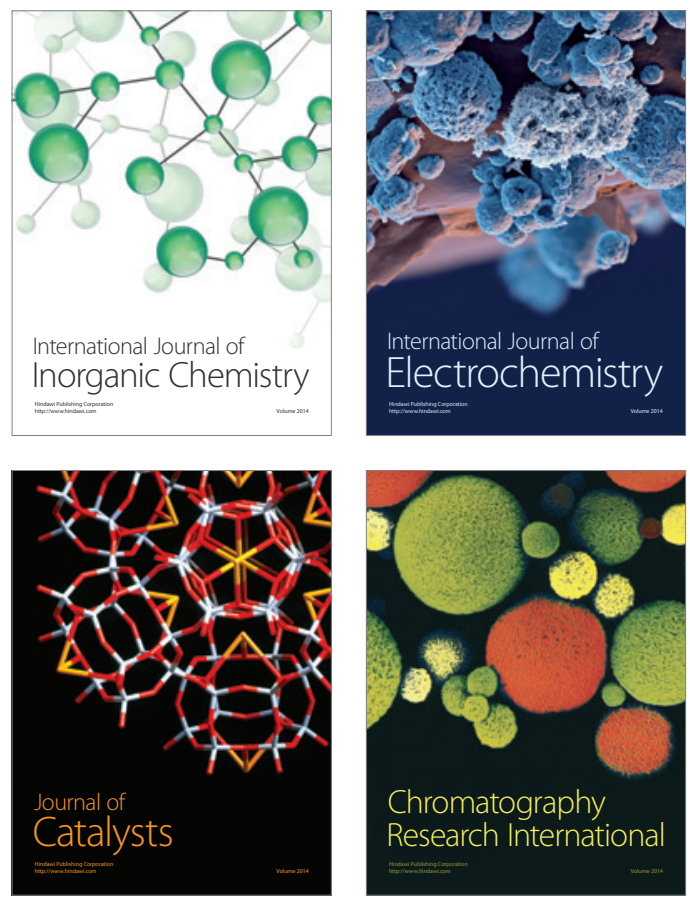
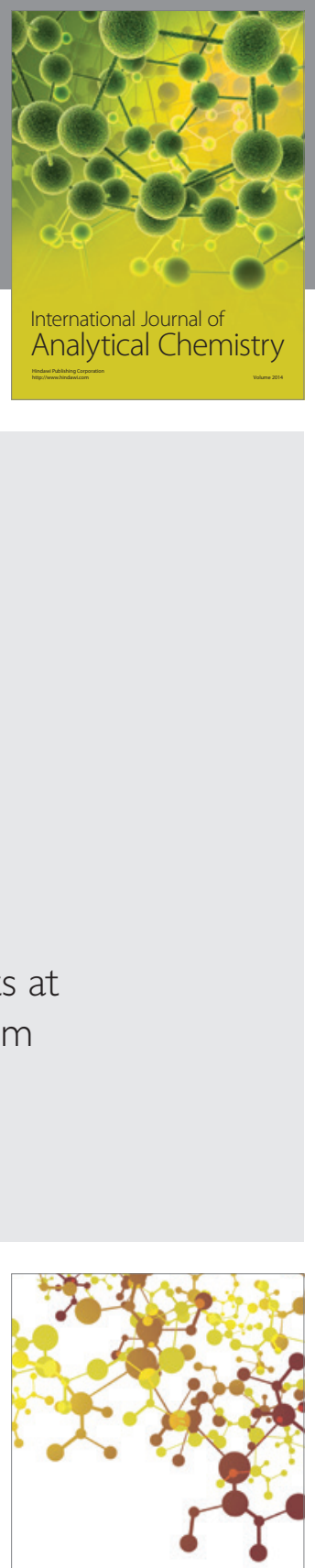

Journal of

Applied Chemistry
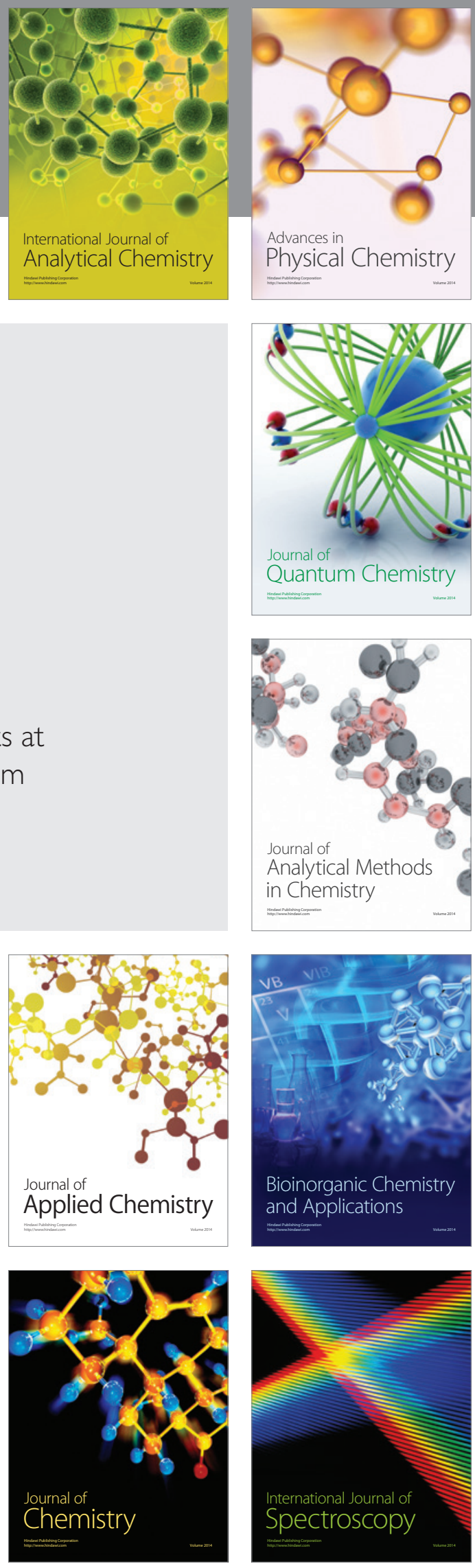